\title{
Structure and dynamics of the planktonic diatom community in the Iguassu River, Paraná State, Brazil
}

\author{
M. S. Nardelli ${ }^{*}$, N. C. Bueno ${ }^{a}$, T. A. V. Ludwig ${ }^{b}$ and A. T. B. Guimarães ${ }^{a}$ \\ aPrograma de Pós-graduação em Conservação e Manejo de Recursos Naturais, Universidade Estadual do Oeste do Paraná - \\ UNIOESTE, Rua Universitária, 2069, Jardim Universitário, CEP 85819-110, Cascavel, PR, Brazil \\ bDepartamento de Botânica, Universidade Federal do Paraná - UFPR, Avenida Coronel Francisco Heráclito dos Santos, 210, \\ Jardim das Américas, CEP 81531-980, Curitiba, PR, Brazil \\ *e-mail: margaretseghetto@hotmail.com
}

Received: August 11, 2014 - Accepted: April 06, 2015 - Distributed: May 31, 2016

(With 7 figures)

\begin{abstract}
The evaluation of abiotic and biotic variables can provide information for understanding the structure and function of lotic systems. To obtain this information, measurements of 15 chemical and physical variables and of phytoplankton were conducted at two sampling stations. The present study aims to evaluate the temporal and spatial variation of planktonic diatoms in terms of abiotic variables and the trophic level of the river water and to select diatom species as descriptors of the physical and chemical conditions of the water upstream (S1) and downstream (S2) of the Iguassu River over an annual cycle. Sampling station S1 was classified as oligotrophic to mesotrophic, and S2 was classified as ultra-oligotrophic to oligotrophic. A total of 98 diatom species distributed among 39 genera was recorded, showing no dominant species but 36 abundant species. Although the differences of chemical and physical variables between $\mathrm{S} 1$ and S2 were limited to greater turbulence and turbidity, processes triggered by heavy rainfall exerted a significant influence on community structure, and a temporal change in composition was observed. At the end of the dry period, due to the recovery of nutrients and high transparency, there was an abundance of Cocconeis placentula var. lineata. In the rainy period, with increased turbulence and turbidity processes resulting from higher rainfall, there was an abundance of Aulacoseira granulata var. granulata.
\end{abstract}

Keywords: nutrient shortage, South America, trophic index.

\section{Estrutura e dinâmica da comunidade de Diatomáceas planctônicas do rio Iguaçu, estado do Paraná, Brasil}

\begin{abstract}
Resumo
A avaliação das variáveis abióticas e bióticas pode prover informações para o entendimento da estrutura e do funcionamento dos sistemas lóticos. No intuito de obter tais informações, quinze variáveis físicas e químicas e o fitoplâncton foram analisadas em duas estações de amostragem. O presente trabalho tem como objetivo avaliar a variação temporal e espacial das diatomáceas planctônicas em função das variáveis abióticas e do nível trófico da água do rio, e eleger populações descritoras das condições físicas e químicas da água a montante (S1) e a jusante (S2) das cataratas do rio Iguaçu, ao longo de um ciclo anual. A estação de amostragem $\mathrm{S} 1$ foi classificada como oligotrófica à mesotrófica $\mathrm{e}$ a S2, de ultraoligotrófica à oligotrófica. Um total de 98 espécies de diatomáceas distribuídas entre 39 gêneros foram registrados, não apresentando espécies dominantes, mas 36 espécies abundantes. Mesmo apresentando diferenças das variáveis químicas e físicas entre S1 e S2, apenas a maior turbulência e turbidez da água, processos desencadeados pela elevada pluviosidade, exerceram papel significativo na estruturação da comunidade, sendo observado mudança temporal na composição. No final do período seco, pela recuperação de nutrientes e pela elevada transparência, observou-se a abundância de Cocconeis placentula var. lineata. No período chuvoso, com maior turbulência e turbidez, processos decorrentes da maior pluviosidade, registrou-se a abundância de Aulacoseira granulata var. granulata.
\end{abstract}

Palavras-chave: América do Sul, escassez de nutrientes, índice trófico. 


\section{Introduction}

The growth of qualitative and quantitative impacts (agriculture, livestock, industry and tourism), isolated or not, leads to the deterioration of water quality and affects the biological integrity of aquatic ecosystems. Among the activities impacting affecting Brazil's major rivers, the construction of numerous dams and waterways stands out (Tundisi, 2003). Based on this assumption, it was seen by Ward and Stanford (1983) that a lotic environment undergoing impoundment may suffer substantial changes in patterns of abiotic processes, and consequently biotic processes, both upstream and downstream of the impoundment.

The Iguassu River, considered a large river, has several dams and is one of the most important rivers (economic and social) of the Iguassu River basin because of its volume of water. The river is divided into three parts: the high, middle and low Iguassu. This last part of the river is in the Iguazu National Park, and because this area is of great importance for biodiversity, it was designated a National Heritage by Decree-lawn 1035 - January 10, 1939 (UNESCO, 2002).

Due to the intensity of this river's impoundments together with other influences such as the occupation of its banks for agriculture, cattle breeding and industry (Paraná, 2010), it has been observed that these systems are constantly under pressure, and changes may be occurring in the river. Such anthropogenic processes may be influencing the structure of the environment and of the communities there in (Tundisi and Matsumura-Tundisi, 2008).

Thus, management actions have been performed to detect these ecological changes by using the following environmental variables for measurement: physical, chemical and biological variables (Stevenson and Pan, 1999). Among the biological variables, diatoms are considered the most successful among algae (Wehr and Descy, 1998) and are commonly used as indicators of water quality (Smol and Stoermer, 2010). In part, the use of diatoms is associated with the response to subtle environmental changes, both for their sensitivity and tolerance, in addition to competitive advantages in lotic environments (Taylor et al., 2007; Smol and Stoermer, 2010).

Regarding structural considerations, physical factors such as climatic conditions can affect the distribution patterns of the diatom community (Jadhav et al., 2011); for example, variation in rainfall levels will increase or decrease the discharge rate, the dilution of the river and its turbulence (Nabout et al., 2007; Moura et al., 2013). Moreover, geomorphological and hydrological characteristics of rivers directly affect the distribution of the community (Centis et al., 2010; Esteves and Suzuki, 2011).

Several taxonomic studies of diatoms in lotic environments have been conducted in Paraná (e.g.: Brassac and Ludwig, 2003, 2005, 2006; Ferrari and Ludwig, 2007; Tremarin et al., 2008, 2009; Santos et al., 2011; Bartozek et al., 2013), as have studies on ecological aspects of periphytic diatoms (e.g.: Borges et al., 2008; Marquardt et al., 2010; Moresco et al., 2011). Ecological studies focusing exclusively on planktonic diatoms are few: Train (1991) assessed a floristic survey of planktonic and periphytic diatoms for potential as biological indicators of ecological conditions, and Contin (1990) also related planktonic and periphytic diatom flora to environmental indexes.

Collecting information on this community is extremely important as a theoretical foundation to management and conservation. Considering the lack of ecological information on large rivers, this study aims to conduct the following: i) evaluate the temporal and spatial variation of planktonic diatoms in terms of abiotic variables and the trophic level of the river water upstream and downstream of the Iguassu falls in the Iguassu River; ii) and select diatom descriptors of the physical and chemical conditions of the water in these two sampling stations and identify factors determining the community structure.

Assuming that diatoms are excellent bioindicators, it is expected that the temporal variation of environmental conditions governed by temperature and precipitation upstream and downstream of the Iguassu falls of the Iguassu River is the most important factor in determining the density, richness, diversity and composition of planktonic diatoms in relation to the physical characteristics of the sampling stations, such as width and depth.

\section{Material and Methods}

The Iguassu River, from its source in Serra do Mar to the mouth of the Paraná River, is 1275 km in length (Paraná, 2010). The climate is humid subtropical (Cfa) (Peel et al., 2007), with physiological drought caused by intense cold (Veloso et al., 1991) and an average annual temperature of $26^{\circ} \mathrm{C}$ (max. $40^{\circ} \mathrm{C} / \mathrm{min} .3{ }^{\circ} \mathrm{C}$ ) (Salamuni et al., 2002). The average precipitation over the basin of the Iguassu River is approximately $1500 \mathrm{~mm}$ /year (LACTEC, 2005).

Two collection sites were selected in the lower Iguassu River, considering their heterogeneity in depth, width and turbulence (Figure 1). Station 1 (S1): located upstream of the falls $\left(25^{\circ} 39^{\prime} \mathrm{S}\right.$ and $\left.54^{\circ} 25^{\prime} \mathrm{W}\right)$, width of 1200 to $869.89 \mathrm{~m}$, less turbulence compared to station 2 (S2) and average speed of $0.42 \mathrm{~ms}^{-1}$. The water depth varies from $0.90 \mathrm{~m}$ (low) reaching $4.62 \mathrm{~m}$ in the months of higher flow, and the margins are protected with native vegetation. Station 2 (S2): located downstream of the falls $\left(25^{\circ} 38^{\prime} \mathrm{S}\right.$ and $\left.54^{\circ} 27^{\prime} \mathrm{W}\right)$, average width of $69.89 \mathrm{~m}$, the water depth varies from $4.62 \mathrm{~m}$ to $27.46 \mathrm{~m}$ in the months of greater flow, with an average speed of $6.8 \mathrm{~ms}^{-1}$. The river banks are covered with native vegetation and rock walls.

Monthly collections were made in the period between September 2010 and September 2011 (except for the month of November 2010) in the sub-surface (c.a. $20 \mathrm{~cm}$ ) of the river for physical, chemical and biological analyses of the water.

Water transparency was measured with a Secchi disc (Esteves and Suzuki, 2011). Measurements of water temperature $\left({ }^{\circ} \mathrm{C}\right)$, dissolved oxygen (DO, mg. $\left.\mathrm{L}^{-1}\right), \mathrm{pH}$, electric conductivity $(\mu \mathrm{S} / \mathrm{cm})$ and turbidity (NTU) were 


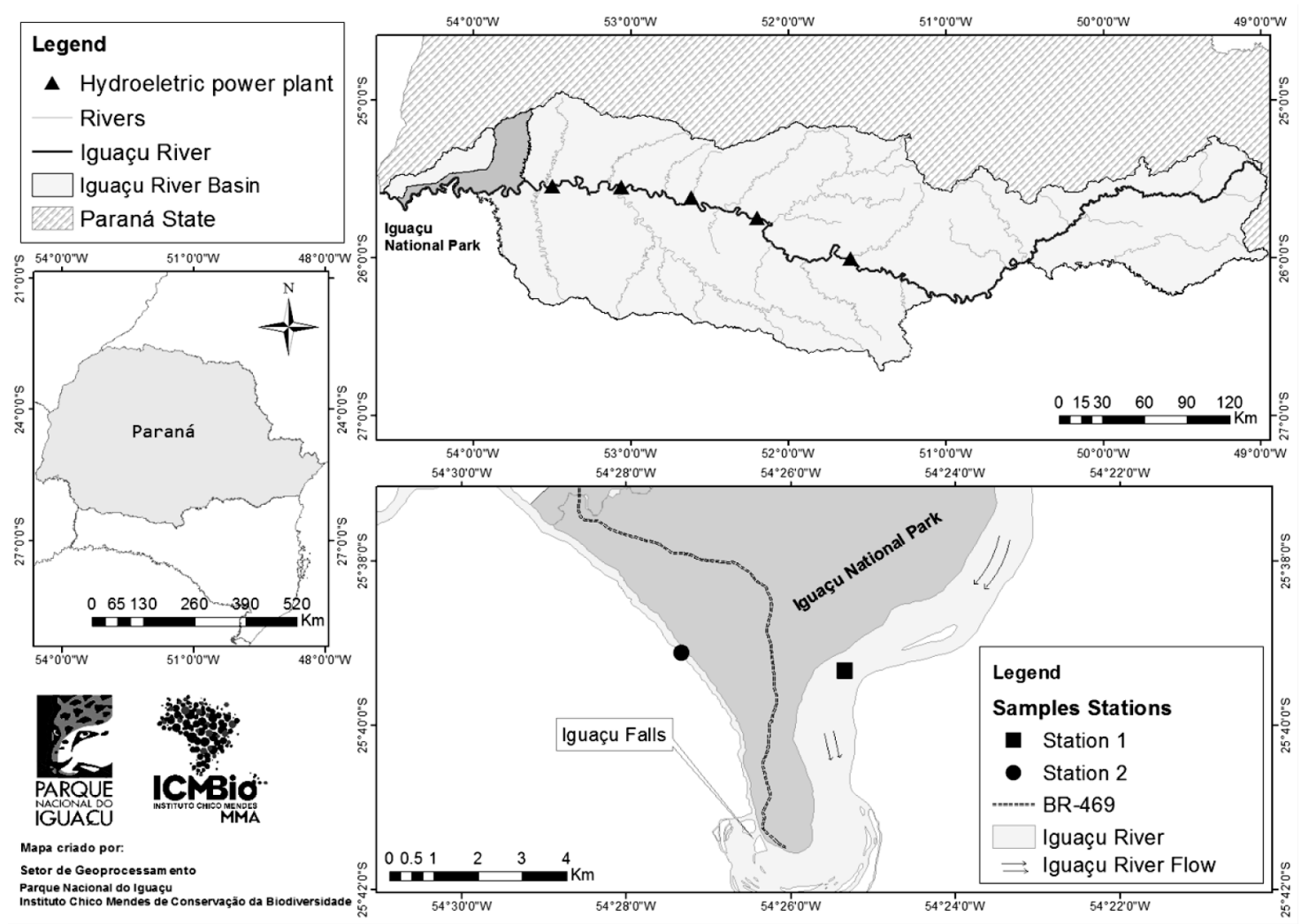

Figure 1. Location of sampling stations: Station 1 upstream (S1) and Station 2 (S2) downstream of the Iguaçu Falls, lower Iguaçu River, Parana.

obtained in situ with the aid of the Horiba multiparameter probe U-50. The chemical oxygen demand (COD) and biochemical oxygen demand (BOD) were estimated according to standard methods (APHA, 2005). The concentrations of total nitrogen (TN), total phosphorus (TP), orthophosphate $\left(\mathrm{PO}_{4}^{-}\right)$and nitrate $\left(\mathrm{N}-\mathrm{NO}_{3}\right)$ were estimated by the method of Mackereth et al. (1978), ammonium $\left(\mathrm{N}_{-} \mathrm{NH}_{4}^{+}\right)$by the method of Solorzano (1969), and chlorophyll $a$ by the method of Marker et al. (1980). Chemical analyses were performed in the laboratory of the Research Group on Fisheries Resources and Limnology-UNIOESTE Toledo campus.

The data relating to rainfall and air temperature were provided by the Meteorological Institute of Paraná (Simepar/Curitiba). For the analysis of pluviometric precipitation, the weekly accumulation of the seven days preceding the sampling was used. Data on flow $\left(\mathrm{m}^{3} / \mathrm{s}\right)$, speed $(\mathrm{m} / \mathrm{s})$ and depth $(\mathrm{m})$ were supplied by Binational Itaipu Company.

A plankton net ( $25 \mu \mathrm{m}$ mesh size) was used to collect samples for qualitative study comprising the taxonomic analysis of phytoplankton, and they were fixed with Transeau solution 1:1 (Bicudo and Menezes, 2006). Species identification was performed on permanent slides prepared with Naphrax ${ }^{\circledR}$ resin and with oxidized samples (Moreira-Filho and Valente-Moreira, 1981), and images were collected with the aid of an Olympus BX70 photomicroscope with a coupled DP 071 camera.

For the quantitative analysis of phytoplankton, water samples were collected directly from the subsurface and fixed with acetic $1 \%$ Lugol solution. Phytoplankton density was estimated by the sedimentation method of Utermöhl (1958). Cells were counted (céls. $\mathrm{mL}^{-1}$ ) when whole and with cell contents in a number of fields sufficient to stabilize the number of species added per field (using the minimum area method), ensuring a minimum qualitative representation of species. The density calculation was performed according to the APHA (APHA, 2005).

Species richness was defined as the total number of taxa found in a given sample. The constancy index was according to Dajoz (2005). The abundance of species in each quantified sample was established following the Lobo and Leighton (1986) standard criteria, in which dominant denotes those species with density greater than $50 \%$ of the total density of the sample and abundant denotes species that exceed the average density.

The index of the trophic status (TSI) of water was established according to Carlson (1977) as modified by Lamparelli (2004), adopting values of trophic river classification for chlorophyll $a$ and total phosphorus (TP).

Descriptive analyses of the community, richness, diversity and evenness were performed for each station 
using PC-Ord 4.0. The diversity data were evaluated using the $t$-test for diversity to test the null hypothesis of equality of communities between stations over the months (Zar, 1998) through the PAST program, version 2.13 (Paleontological Statistics Software Package for Education and Data Analysis) (Hammer et al., 2011).

To evaluate the relationship between each of the abundant species and each of the abiotic variables, Spearman nonparametric correlation analysis was applied (Zar, 1998). The species showing at least one significant correlation $(p<0.05)$ were selected for canonical correspondence analysis (CCA) conducted under the routine proposed by Ter-Braak (1986), which does not require data normalization, applying the Monte Carlo permutation test with 5000 permutations and assuming $\mathrm{p}<0.05$.

The evaluation of similarity between the two sampling stations and the respective months was performed by the agglomerative hierarchical cluster analysis method with the unweighted pair-group average (UPGMA) method of clustering and Bray-Curtis dissimilarity measure. The explicability of the grouping was evaluated by calculating the coefficient of cophenetic correlation. These analyses were performed using the XLSTAT program 2012.1.01.

\section{Results}

The weekly rainfall data revealed that the highest values of rainfall $(132.6 \mathrm{~mm})$ occurred in August, which is unusual for this period, as it is typically considered a dry period (Figure 2).

The water level of the Iguassu River ranged from 1.4 to $3.0 \mathrm{~m}$ at S1 and 11.7 to $27.4 \mathrm{~m}$ at S2. The lowest atmospheric temperature was found in June $\left(13.2^{\circ} \mathrm{C}\right)$ and the highest in January $\left(35.2^{\circ} \mathrm{C}\right)$, registering atypical high temperature on September $2011\left(33.7^{\circ} \mathrm{C}\right)$. The water temperature showed the same pattern of variation at both stations with a range of $14^{\circ} \mathrm{C}$. The average turbidity values were similar at both stations, and the highest occurred concomitantly with higher values of precipitation and conductivity. The lowest values of transparency occurred at $\mathrm{S} 2$ and the highest, in May, at both stations. The $\mathrm{pH}$

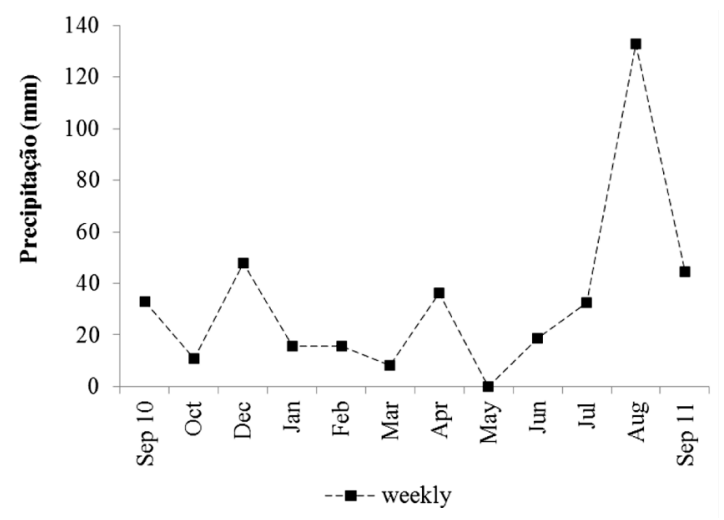

Figure 2. Accumulated variation weekly rainfall, the seven days before the Sampling. values ranged between 6.1 and 8.7 at $\mathrm{S} 1$ and between 5.9 and 8.3 at S2. The highest values of DO, BOD, COD and orthophosphate $\left(\mathrm{PO}_{4}^{-}\right)$were recorded at $\mathrm{S} 2$. The highest concentrations of ammonium ion $\left(\mathrm{NH}_{4}^{+}\right)$, nitrate $\left(\mathrm{NO}_{3}^{-}\right)$, total phosphorus (TP) and chlorophyll $a$ occurred at S1. The concentration of total nitrogen (TN) was similar between the stations (Table 1).

The trophic state index (TSI) calculated showed that S1 was classified as mesotrophic (TSI $=57$ in January, 2011) to oligotrophic (TSI=50 in May, 2011), and S2 as mesotrophic (TSI=56.5 in January, 2011) to ultra-oligotrophic (TSI=34.9 in May, 2011) (Figure 3).

The infra-generic taxa determined were 98, with 74 common to both sampling stations; 39 genera were represented, distributed among the Coscinodiscophyceae (9), Fragilariophyceae (3) and Bacillariophyceae (27) classes. The total richness at each of the stations was 86 taxa, and despite the numerical coincidence, 12 taxa were found only at S1 and another 12 at S2 (Table 2).

Most of the identified species ( $80 \%$ ) showed structures for attachment to substrates for a greater or lesser level of adhesion. Despite the large number of periphytic diatoms, $77 \%$ were sporadic or occasional. Only $29 \%$ of species considered planktonic were found, which were also sporadic or occasional.

Throughout the study period, the accumulated density values were quite close between the stations ( $\mathrm{S} 1=5654 \mathrm{cel}$. $\mathrm{mL}^{-1}$ and $\mathrm{S} 2=5344$ cel. $\mathrm{mL}^{-1}$ ). In most months, the density was higher in S2, except in June and August 2011 when they were higher in S1.

Bacillariophyceae was the most represented class in number of individuals, with the highest percentage contribution in seven months of collection; in June 2011, the highest peak of the class was recorded at both stations. Coscinodiscophyceae occurred in greater density in August at $\mathrm{S}$, and the Fragilariophyceae, at low density, were less frequent in the collections (Figure 4).

Out of the total cumulative density, more than $50 \%$ was represented by the genera Aulacoseira Thwaites (3843 cel. $\left.\mathrm{mL}^{-1}\right)$, Cocconeis Ehrenberg $\left(1090\right.$ cel. $\left.\mathrm{mL}^{-1}\right)$ and

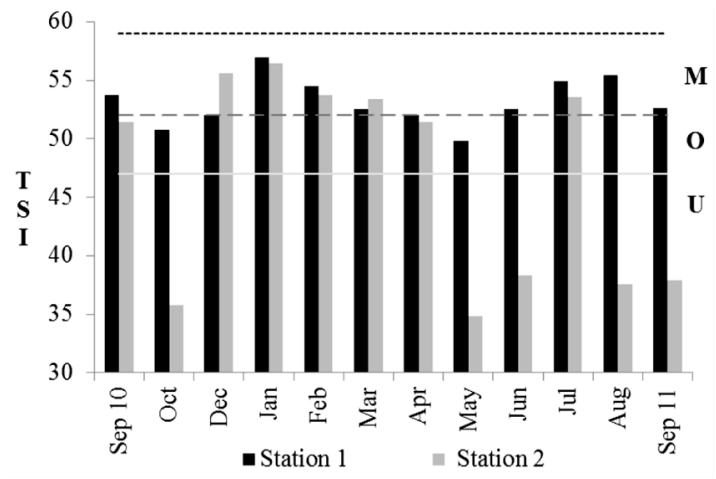

Figure 3. Monthly variation of trophic state index (TSI) for S1 and S2 (U - ultra-oligotrophic <47, O - oligotrophic 47-51, M - mesotrophic 52-59). 
Table 1.Values minimum, maximum, mean, standard deviation and coefficient of variation for $\mathrm{S} 1$ and $\mathrm{S} 2$, for the sampling period. Water temperature $\left(\mathrm{Ta}{ }^{\circ} \mathrm{C}\right) ; \mathrm{pH}$; Dissolved oxygen (DO mg. $\left.\mathrm{L}^{-1}\right)$; Biochemical Oxygen Demand (BOD mg. $\mathrm{L}^{-1}$ ); Chemical Oxygen Demand (COD mg. $\mathrm{L}^{-1}$ ); Electrical Conductivity $\left(\right.$ Cond $\mu \mathrm{S} . \mathrm{cm}^{-1}$ ); Secchi Transparency (SD m); Turbidity (NTU); Ammonium (NH4 $\mu \mathrm{g} . \mathrm{L}^{-1}$ ); Total Nitrogen (TN $\mu \mathrm{g} . \mathrm{L}^{-1}$ ); Nitrate (NO3 $\mu \mathrm{g} . \mathrm{L}^{-1}$ ); Total phosphorus $\left(\mathrm{TP} \mu \mathrm{g} . \mathrm{L}^{-1}\right)$; Orthophosphate $\left(\mathrm{PO}_{4}^{-} \mu \mathrm{g} . \mathrm{L}^{-1}\right)$; Chlorophyll $a\left(\mathrm{Clo} a \mu \mathrm{g} . \mathrm{L}^{-1}\right)$; Depth $(\mathrm{m})$.

\begin{tabular}{|c|c|c|c|c|c|c|c|c|c|c|}
\hline Station & \multicolumn{5}{|c|}{ S1 } & \multicolumn{5}{|c|}{ S2 } \\
\hline Parameters & Min & Max & Med & SD & CV (\%) & Min & Max & Med & SD & CV (\%) \\
\hline Water $\mathrm{T}^{\circ} \mathrm{C}$ & 15.5 & 28.6 & 21.8 & 3.7 & 16.9 & 15.9 & 28.8 & 21.9 & 3.8 & 17.4 \\
\hline $\mathrm{pH}$ & 6.1 & 8.7 & 7.2 & 0.6 & 8.3 & 5.9 & 8.3 & 7.3 & 0.7 & 10.1 \\
\hline DO mg.L L $^{-1}$ & 6.4 & 12.2 & 8.7 & 1.6 & 18.3 & 6.6 & 13.1 & 9.5 & 1.7 & 18 \\
\hline BOD mg.L ${ }^{-1}$ & 0.9 & 11.4 & 4.7 & 3.1 & 65.2 & 1.8 & 13.9 & 5.9 & 3.3 & 55.8 \\
\hline COD mg.L ${ }^{-1}$ & 6.8 & 21.6 & 13.9 & 3.8 & 27.9 & 4.7 & 25.9 & 12.6 & 5.6 & 44.9 \\
\hline Cond $\mu$ S.cm ${ }^{-1}$ & 32.8 & 105.0 & 45.2 & 18.7 & 41.4 & 34.0 & 87.0 & 44.9 & 13.7 & 30.6 \\
\hline $\mathrm{SD} \mathrm{m}$ & 0.9 & 3.6 & 1.74 & 0.6 & 35.4 & 0.7 & 3.6 & 1.47 & 0.8 & 52.8 \\
\hline NTU & 2.0 & 26.1 & 9.5 & 6.8 & 71.4 & 2.8 & 23.2 & 10.7 & 7.3 & 67.9 \\
\hline $\mathrm{NH}_{4}^{+} \mu \mathrm{g} \cdot \mathrm{L}^{-1}$ & 0.8 & 123.2 & 33.5 & 34.9 & 104.3 & 0.4 & 70.4 & 23.8 & 19.9 & 83.5 \\
\hline $\mathrm{TN} \mu \mathrm{g} . \mathrm{L}^{-1}$ & 100.0 & 500.0 & 280.0 & 109.4 & 39.1 & 110.0 & 500.0 & 260.8 & 139.6 & 53.5 \\
\hline $\mathrm{NO}_{3}^{-} \mu \mathrm{g} \cdot \mathrm{L}^{-1}$ & 100.0 & 2140.0 & 1020.0 & 693.3 & 68 & 100.0 & 1730.0 & 939.2 & 569.2 & 60.6 \\
\hline $\mathrm{TP} \mu \mathrm{g} . \mathrm{L}^{-1}$ & 20.0 & 450.0 & 155.8 & 116.7 & 74.9 & 50.0 & 390.0 & 175.8 & 95.6 & 54.4 \\
\hline $\mathrm{PO}_{4}^{-} \mu \mathrm{g} \cdot \mathrm{L}^{-1}$ & 124.3 & 137.7 & 130.0 & 4.4 & 3.4 & 123.5 & 144.3 & 130.6 & 6.1 & 4.7 \\
\hline Clo $a \mu \mathrm{g} . \mathrm{L}^{-1}$ & 0.3 & 0.8 & 0.5 & 0.2 & 44.7 & 0.1 & 0.5 & 0.2 & 0.2 & 62.6 \\
\hline Depth m & 1.4 & 3.0 & 2.1 & 0.6 & 26.9 & 11.7 & 27.4 & 19.0 & 4.6 & 24.2 \\
\hline
\end{tabular}

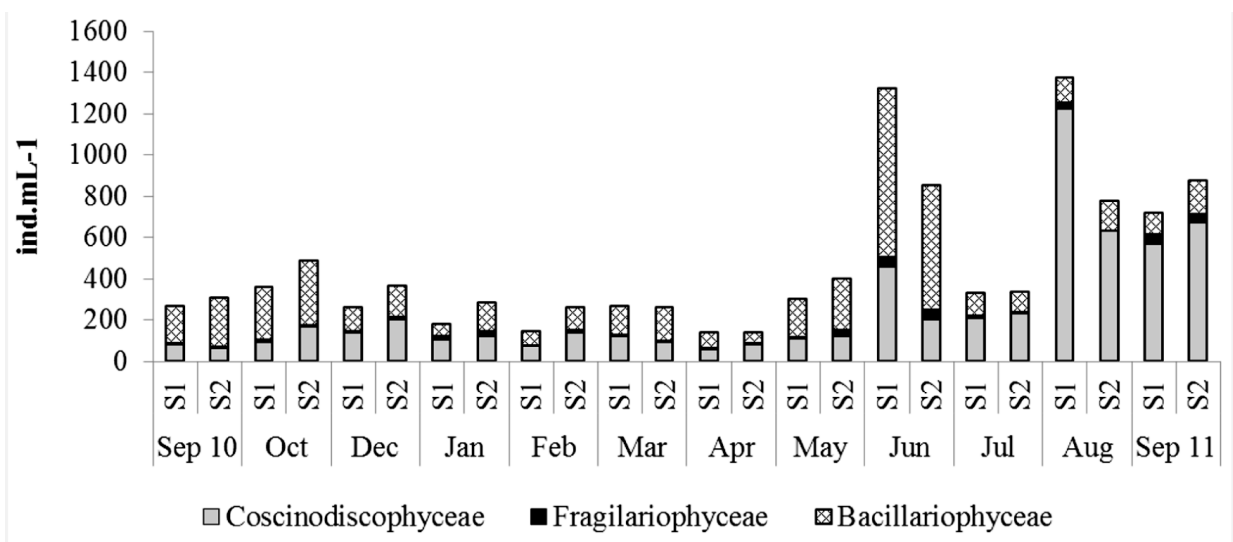

Figure 4. Variation of the diatoms density by taxonomic class.

Achnanthidium Kützing (1052 cel.mL $\left.\mathrm{mL}^{-1}\right)$. The most represented species of these genera were Aulacoseira granulata var. granulada $\left(1414\right.$ cel. $\left.\mathrm{mL}^{-1}\right)$, A. pusilla $\left(1191\right.$ cel. $\left.\mathrm{mL}^{-1}\right)$ and A. granulata var. angustissima $\left(665\right.$ cel. $\left.\mathrm{mL}^{-1}\right)$; Cocconeis placentula var. lineata $\left(1090\right.$ cel. $\left.\mathrm{mL}^{-1}\right)$; Achnanthidium minutissimum $\left(689\right.$ cel. $\left.\mathrm{mL}^{-1}\right)$, A. lineare $\left(275\right.$ cel. $\left.\mathrm{mL}^{-1}\right)$ and $A$. exiguum var. constrictum $\left(87\right.$ cel. $\left.\mathrm{mL}^{-1}\right)$.

No dominant species were recorded throughout the study period. There were 36 abundant species, with 23 being common between stations. The highest number of abundant species occurred in May 2011 for S1 (14) and in June 2011 for S2 (12), coinciding with the highest water transparency. July, August and September 2011, with the lowest number of abundant taxa, were months of higher turbidity (Table 2, Figure 5).

Values of diversity, evenness and richness were estimated for the two sampling stations. In September, October and
December 2010 there was greater diversity at S1 ( $t$-test; $\mathrm{p}<0.05)$ due to its greater evenness, but richness was equal between the stations. In January and February 2011, diversity was higher at $\mathrm{S} 2(t$-test; $\mathrm{p}<0.05)$ due to its greater richness, yet abundance values were similar between the stations. In May 2011, the greatest diversity occurred at S1 ( $t$-test; $\mathrm{p}<0.05)$ due to greater richness. It was noted that in the months of July, August and September 2011, the lowest values of ecological attributes occurred at both stations. In July and August, significant differences were observed ( $t$-test; $\mathrm{p}>0.05$ ); however, there were no differences in the month of September ( $t$-test; $\mathrm{p}>0.05$ ) (Table 3 ).

Clustering analysis obtained between sampling stations based on all species identified four groups with temporal separation and a cophenetic value of 0.82 . Group 1 (G1) was gathered at both stations in the month of April 2011 during 
lower $\mathrm{pH}$ and phosphorus levels, a month characterized especially by Pleurosira laevis.

Group 2 (G2), clustering in the months of July, August and September 2011 at the two stations (months with lower values of evenness and richness and higher density of species in the Coscinodiscophyceae class), was represented by the genus Aulacoseira. This period was characterized by higher levels of rainfall and high values of conductivity, depth, turbidity, BOD, DO and chlorophyll $a$, in addition to the increased values of total phosphorus in July.

Group 3 (G3), gathered at both sampling stations in the month of June 2011 (a month characterized by higher richness $(\mathrm{S} 1=43$ and $\mathrm{S} 2=41)$ and higher densities of species of the Bacillariophyceae class), was represented

Table 2. Values of medium density (céls.mL-1), standard deviation (SD), coefficient of variation (CV\%) in S1 and S2 of 36 abundant species indicating the figures (Figure 5).

\begin{tabular}{|c|c|c|c|c|c|c|c|}
\hline \multicolumn{2}{|l|}{ Abundant species } & \multicolumn{3}{|c|}{ Station 1} & \multicolumn{3}{|c|}{ Station 2} \\
\hline Bacillariophyceae & Fig & Med & SD & $\mathbf{C V}$ & Med & SD & $\mathbf{C V}$ \\
\hline $\begin{array}{l}\text { Achnanthidium exiguum var. constrictum (Grunow) Andresen, } \\
\text { Stoermer and Kreis }\end{array}$ & $\mathbf{a}$ & 3 & 6 & 212 & 4 & 5 & 146 \\
\hline A. lineare Smith & c & 14 & 22 & 157 & 9 & 12 & 139 \\
\hline A. minutissimum (Kützing) Czarnecki & b & 30 & 32 & 107 & 27 & 17 & 61 \\
\hline Cocconeis placentula var. acuta Meister & $\mathbf{w}$ & 3 & 7 & 210 & 4 & 6 & 139 \\
\hline C. placentula var. euglypta (Ehrenberg) Grunow & $\mathbf{u}$ & 3 & 5 & 157 & 2 & 5 & 213 \\
\hline C. placentula var. lineata (Ehrenberg) Van Heurck & $\mathbf{v}$ & 32 & 41 & 127 & 45 & 48 & 106 \\
\hline Encyonema silesiacum (Bleisch) Mann & $\mathbf{q}$ & 6 & 6 & 114 & 10 & 9 & 90 \\
\hline Eunotia sudetica O. Muller & $\mathbf{y}$ & 5 & 6 & 122 & 7 & 10 & 148 \\
\hline $\begin{array}{l}\text { Geissleria punctifera Metzeltin, Lange-Bertalot and Garcia- } \\
\text { Rodriguez }\end{array}$ & $\mathbf{n}$ & 5 & 6 & 135 & 4 & 4 & 109 \\
\hline $\begin{array}{l}\text { Gomphonema brasiliensoide Metzeltin Lange-Bertalot and } \\
\text { Garcia-Rodriguez }\end{array}$ & $\mathbf{s}$ & 6 & 7 & 116 & 10 & 12 & 119 \\
\hline G. gracile Ehrenberg & $\mathbf{t}$ & 7 & 5 & 83 & 14 & 16 & 115 \\
\hline G. parvulum Kützing & $\mathbf{0}$ & 2 & 4 & 228 & 0 & 1 & 229 \\
\hline Gomphonema sp. & $\mathbf{r}$ & 3 & 4 & 135 & 5 & 5 & 105 \\
\hline Gyrosigma acuminatum (Kützing) Rabenhorst & $\mathbf{x}$ & 2 & 4 & 225 & 0 & 0 & 0 \\
\hline Navicula cryptocephala Kützing & ad & 1 & 2 & 281 & 0 & 1 & 332 \\
\hline N. cryptotenella Lange-Bertalot & ae & 5 & 4 & 93 & 4 & 5 & 121 \\
\hline N. rostellata Kützing & ac & 4 & 5 & 129 & 5 & 6 & 114 \\
\hline Nitzschia palea (Kützing) Smith & $\mathbf{z}$ & 1 & 2 & 176 & 3 & 3 & 119 \\
\hline Planothidium frequentissimum Lange-Bertalot & $\mathbf{a b}$ & 28 & 43 & 153 & 20 & 19 & 93 \\
\hline P. rostratum (Østrup) Lange-Bertalot & ag & 3 & 6 & 240 & 5 & 8 & 156 \\
\hline \multicolumn{8}{|l|}{ Coscinodiscophyceae } \\
\hline Aulacoseira ambigua var. ambigua (Grunow) Simonsen & e & 8 & 17 & 220 & 7 & 13 & 193 \\
\hline A. ambigua var. ambigua f. spiralis (Skuja) Ludwig & d & 23 & 66 & 284 & 8 & 15 & 181 \\
\hline A. granulata var. angustissima (O. Müller) Simonsen & g & 55 & 89 & 163 & 63 & 99 & 157 \\
\hline A. granulata var. granulata (Ehrenberg) Simonsen & $\mathbf{h}$ & 31 & 40 & 131 & 25 & 50 & 205 \\
\hline A. pusilla (Meister) Tuji e Houk & f & 59 & 82 & 139 & 40 & 34 & 86 \\
\hline Cyclotella meneghiniana Kützing & $\mathbf{j}$ & 5 & 8 & 158 & 4 & 6 & 159 \\
\hline Cyclotella sp. & i, i1 & 16 & 12 & 76 & 9 & 7 & 74 \\
\hline Discostella stelligera (Cleve e Grunow) Houk and Klee & $\mathbf{k}, \mathbf{L}$ & 33 & 42 & 125 & 23 & 22 & 100 \\
\hline Hydrosera whampoensis (Schwarz) Deby & ah & 6 & 12 & 181 & 11 & 15 & 131 \\
\hline Melosira varians Agardh & aa & 7 & 6 & 86 & 11 & 6 & 49 \\
\hline Pleurosira laevis Compère & ai & 5 & 8 & 168 & 10 & 14 & 142 \\
\hline $\begin{array}{l}\text { Spicaticribra rudis (Tremarin, Ludwig, Becker and Torgan) Tuji, } \\
\text { Leelahakriengkrai and Peerapornpisal }\end{array}$ & af & 13 & 15 & 121 & 12 & 11 & 90 \\
\hline Terpsinoё musica Ehrenberg & ak & 7 & 15 & 228 & 2 & 3 & 153 \\
\hline \multicolumn{8}{|l|}{ Fragilariophyceae } \\
\hline Fragilaria fragilariodes (Grunow) Cholnoky & $\mathbf{p}$ & 7 & 9 & 143 & 7 & 11 & 149 \\
\hline F. vaucheriae (Kützing) Petersen & $\mathbf{m}$ & 1 & 3 & 244 & 0 & 0 & 0 \\
\hline Synedra goulardii Brebisson ex Cleve and Grunow & aj & 2 & 3 & 147 & 4 & 6 & 130 \\
\hline
\end{tabular}




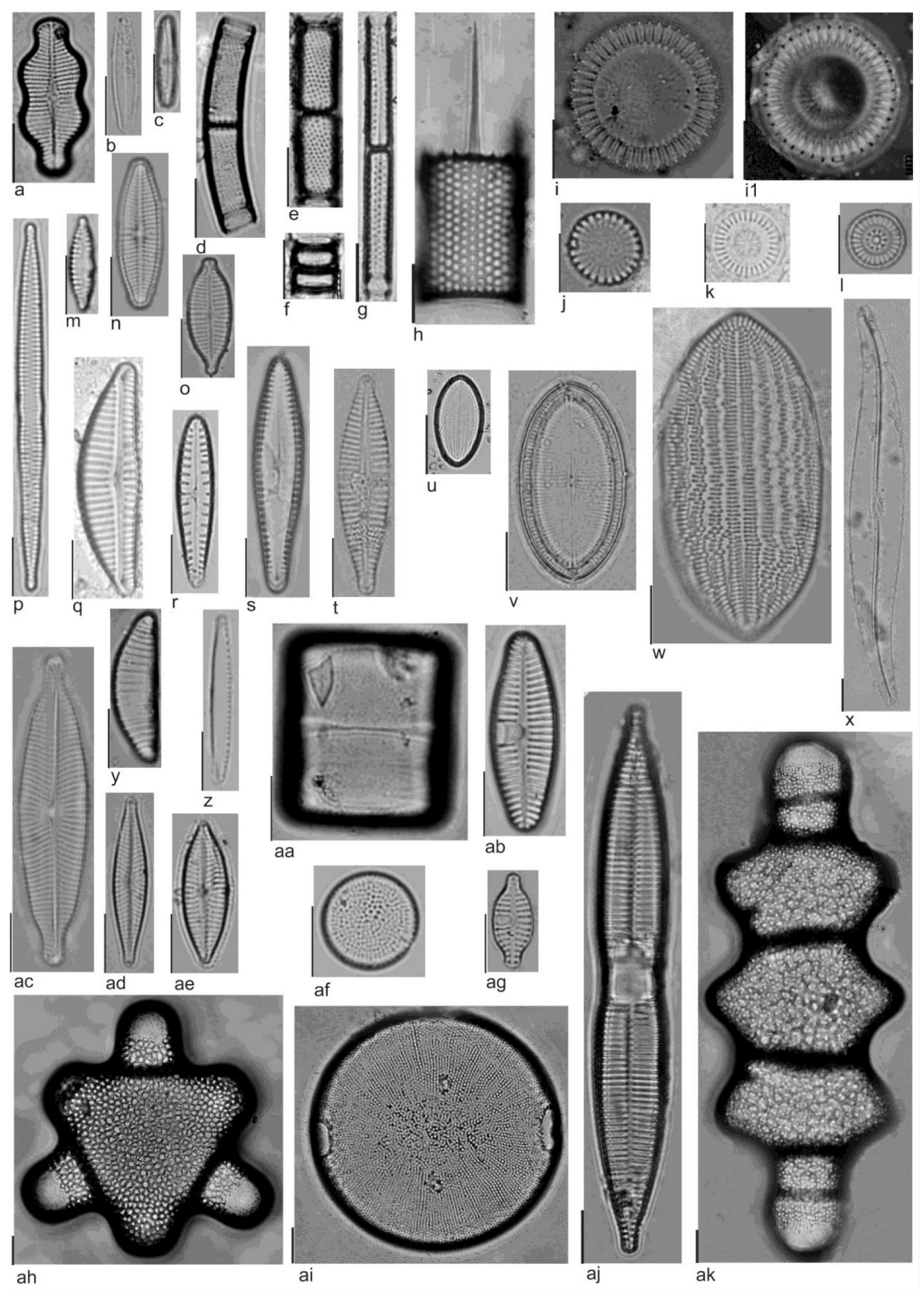

Figure 5. (a-ak) Illustration of the abundant diatom taxa: (a) Achnanthidium exiguum var. constrictum, (b) A. minutissimum, (c) A. lineare, (d) Aulacoseira ambigua var. ambigua f. spiralis, (e) A. ambigua var. ambigua, (f) A. pusilla, (g) A. granulata var. angustissima, (h) A. granulata var. granulata, (i-i1) Cyclotella sp., (j) C. meneghiniana, (k-1) Discostella stelligera, (m) Fragilaria vaucheriae, (n) Geissleria punctifera, (o) Gomphonema parvulum, (p) Fragilaria fragilarioides, (q) Encyonema silesiacum, (r) Gomphonema sp., (s) G. brasiliensoide, (t) G. gracile, (u) Cocconeis placentula var. euglypta, (v) C. placentula var. lineata, (w) C. placentula var. acuta, (x) Gyrosigma acuminatum, (y) Eunotia sudetica, (z) Nitzschia palea, (aa) Melosira varians, (ab) Planothidium frequentissimum, (ac) Navicula rostellata, (ad) Navicula cryptocephala, (ae) N. cryptotenella, (af) Spicaticribra rudis, (ag) Planothidium rostratum, (ah) Hydrosera whampoensis, (ai) Pleurosira laevis, (aj) Synedra goulardii, (ak) Terpsinoё musica. 
by the genera Cocconeis (C. placentula var. lineata), Achnanthidium (A. minutissimum) and Planothidium (P. frequentissimum). The highest values of ecological attributes (richness and density of species of the Bacillariophyceae class) were related to low temperature and lower values of depth, turbidity, ammonium ion, nitrate, COD, BOD and chlorophyll $a$.

Group 4 (G4), gathered in the months of September, October and December 2010 and January to March and May 2011 at both stations, was characterized by low density values of most species. It was possible to verify that in these months there were higher values of water transparency (Figure 6).

Through the Spearman correlation, the following variables were selected for use in CCA: Turbidity, BOD,

Table 3. Test values ( $t$-test) to detect differences in diversity along the months between stations, significant variables $(\mathrm{p}<0.05)$.

\begin{tabular}{lccccc}
\hline \multirow{2}{*}{ Month } & Station1 & & Station2 & & t-test \\
\cline { 2 - 2 } \cline { 5 - 5 } \cline { 5 - 5 } September 2010 & Diversity & & Diversity & & p valor \\
\hline October 2010 & 3.17 & & 2.83 & & $<0.05$ \\
December 2010 & 3.02 & & 2.89 & & $<0.05$ \\
January 2011 & 2.72 & & 3.18 & & $<0.05$ \\
February 2011 & 2.87 & & 3.13 & & $<0.05$ \\
March 2011 & 2.70 & & 2.74 & & $<0.05$ \\
April 2011 & 2.74 & & 2.59 & & $>0.05$ \\
May 2011 & 3.15 & & 2.81 & & $<0.05$ \\
June 2011 & 3.15 & & 3.13 & & $>0.05$ \\
July 2011 & 2.26 & & 2.47 & $<0.05$ \\
August 2011 & 2.19 & & 2.08 & $<0.05$ \\
September 2011 & 2.46 & 2.45 & $>0.05$ \\
\hline
\end{tabular}

DO, TP, $\mathrm{pH}$, transparency, Achnanthidium exiguum var. constrictum, A. lineare, A. minutissimum, Aulacoseira granulata var. granulata, A. granulata var. angustissima, A. ambigua f. spiralis, A. ambigua var. ambigua, A. pusilla, Cocconeis placentula var. lineata, Geissleria punctifera, Hydrosera whampoensis, Pleurosira laevis, Synedra goulardii, and Spicaticribra rudis $(\mathrm{p}<0.05)$.

The CCA explains $83 \%$ of the data variation, indicating that the origin of species is linearly related to the abiotic data (pseudo- $\mathrm{F}=1.97 ; \mathrm{p}=0.007$ ). In this analysis, it was possible to define two axes of ordination. The first axis explains $68.8 \%$ of the data (eigenvalue $=0.355$ ), and the negative scores on this axis indicate greater contributions of BOD, DO and turbidity variables in the months of August and September at both stations, months characterized by increased rainfall. The species most closely related to these conditions were Aulacoseira granulata var. granulata, A. granulata var. angustissima, A. ambigua var. ambigua f. spiralis and A. ambigua var. ambigua. Positive scores show higher contributions of transparency, a variable with higher values in the months of lower rainfall, with higher abundance of the species Achnanthidium lineare, Cocconeis placentula var. lineata, Synedra goulardii, Hydrosera whampoensis, Achnanthidium minutissimum, Spicaticribra rudis and Geissleria punctifera (Figure 7, Table 4).

The second axis explains $14.2 \%$ (eigenvalue $=0.073$ ). Negative scores on this axis are related to TP and $\mathrm{pH}$ variables, with higher values in July, and special focus on Aulacoseira pusilla. The opposite situation, represented by positive axis scores, relates to the lowest values of TP and $\mathrm{pH}$ in the months of February and April and greater abundance of the species Pleurosira laevis (Figure 7, Table 4).

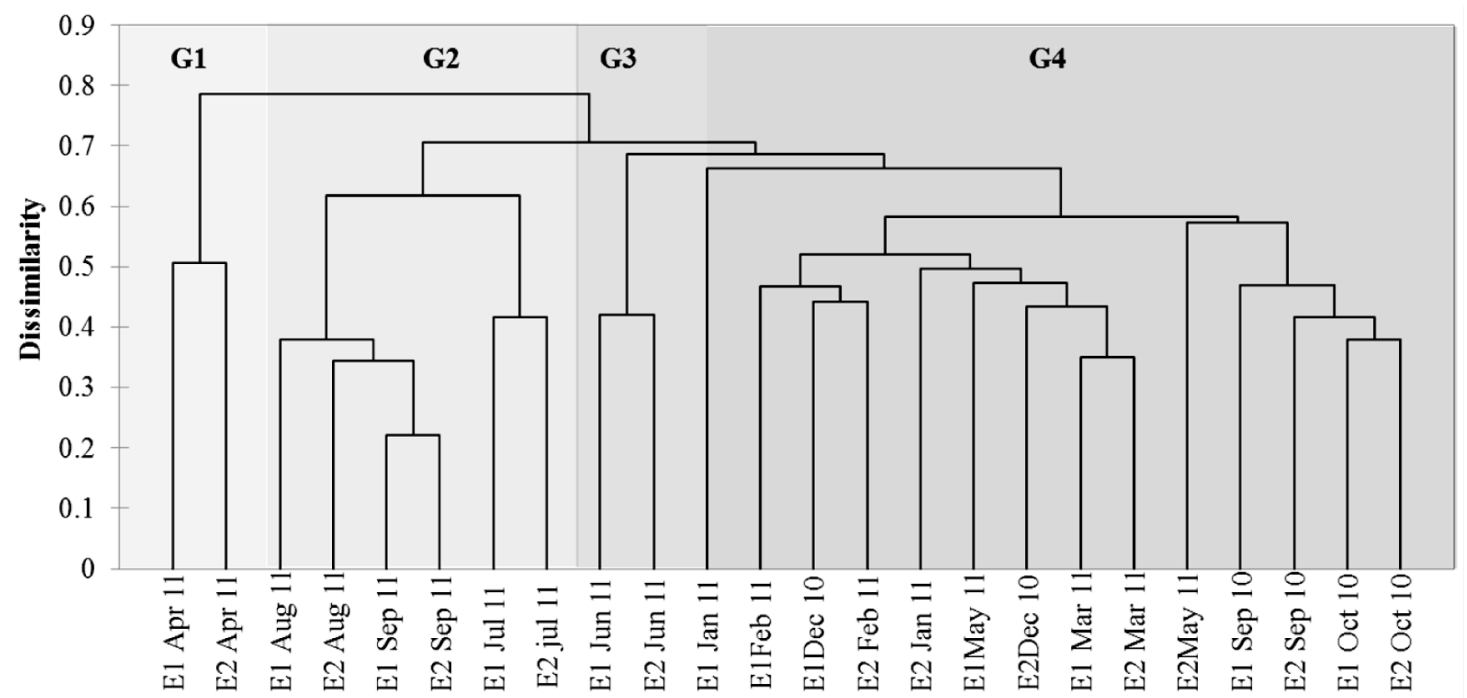

Figure 6. Dendrogram resulting from cluster analysis based on Bray-Curtis dissimilarity of the densities of all species of the two stations. 


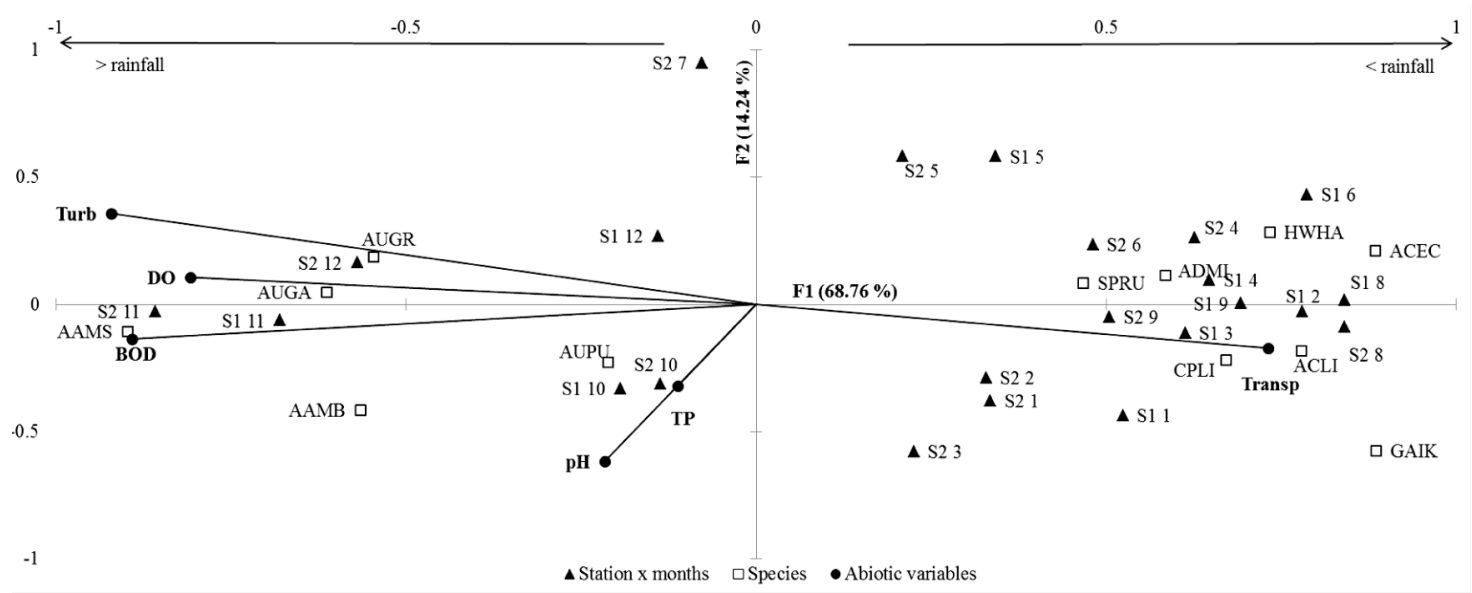

Figure 7. Ordination by CCA with 14 species (codes in Table 4) and six variables (DO, BOD, turbidity, pH, TP and transparency) significant $(\mathrm{p}<0.05)$ in the sampling stations.

Table 4. Values of the regression coefficients of species and abiotic variables, with the principal axes of the CCA.

\begin{tabular}{clcc}
\hline Code & \multicolumn{1}{c}{ Species } & Axis1 & Axis2 \\
\hline ACEC & Achnanthidium exiguum var. constrictum & 0.026 & 0.007 \\
ACLI & Achnanthidium lineare & 0.071 & 0.019 \\
ADMI & Achnanthidium minutissimum & 0.099 & 0.018 \\
AAMB & Aulacoseira ambigua var. ambigua & 0.024 & 0.063 \\
AAMS & A. ambigua var. ambigua f. spiralis & 0.130 & 0.009 \\
AUGR & A. granulata var. granulata & 0.178 & 0.099 \\
AUGA & A. granulata var. angustissima & 0.105 & 0.003 \\
AUPU & A. pusilla & 0.022 & 0.128 \\
CPLI & Cocconeis placentula var. lineata & 0.177 & 0.092 \\
GPTF & Geissleria punctifera & 0.034 & 0.069 \\
HWHA & Hydrosera whampoensis & 0.049 & 0.035 \\
PLEV & Pleurosira laevis & 0.022 & 0.425 \\
SPRU & Spicaticribra rudis & 0.035 & 0.028 \\
SGOU & Synedra goulardii & 0.027 & 0.004 \\
\hline Variables & & & -0.447 \\
& pH & 0.092 & 0.361 \\
& Transparency & 0.153 & -0.707 \\
& DO & -0.294 & 1.683 \\
& Turbidity & -0.114 & -0.625 \\
& BOD & -0.606 & -0.543 \\
\hline
\end{tabular}

\section{Discussion}

Natural peculiarities of lotic environments, such as physical characteristics, are structural builders of potamoplanktonic communities (Esteves and Suzuki, 2011; Mischke et al., 2011). However, the planktonic diatom composition from the two sampling units was similar, even with the landform (Iguassu falls) interposition and with the different depth and width of each investigated location. Probably, these particular physical factors were less significant at determining changes in the structure and composition of this community due to the lower Iguassu being a vast stretch of this large river, with high water flow.
However, temporal variation in the community structure was observed because of environmental alterations. In periods of low rainfall and higher transparency, there was a greater abundance of Cocconeis placentula var. lineata, a species with preference for greater luminosity that is one of the most common taxa in freshwater bodies and seems to be cosmopolitan. Van Dam et al. (1994) and Monnier et al. (2007) claim that these species are good indicators of water quality, preferring oligotrophic habitats, and these data corroborate with the study environment.

Although greater water turbulence and turbidity, which are processes triggered by heavy rainfall, played a significant 
role in structuring the community, it was demonstrated by Nabout et al. (2007) that rainfall can locally influence planktonic composition and by Centis et al. (2010) that physical constraints such as water discharge and turbidity play a determining role in the structure of community.

During this period, some species of centric diatoms were highlighted, especially those of the genus Aulacoseira. Relatively few planktonic organisms are successful in rivers, such as the centric diatoms (Round et al., 1990). The species of this genus are generally characterized by selective properties, such as a high capacity for exploration and opportunistic development (Becker and Motta-Marques, 2004). Additionally, they depend on turbulence to remain in the euphotic zone (Sommer and Stabel, 1983; Costa-Böddeker et al., 2012) because otherwise they would easily inhabit the sediment because of their high density due to the structure of their strongly silicified cell walls.

For example, Aulacoseira granulata has been associated with physical changes such as turbulence (Dong et al., 2008) and decreased light availability (CostaBöddeker et al., 2012). This species is also reported by several authors to present adaptive strategies such as centric and filamentous morphology, higher possibility of fluctuation, high surface/volume ratio, and larger area to capture solar energy (Hill, 1996; Siver and Kling, 1997; Passy, 2007). It is also commonly associated with mesotrophic to eutrophic environments, showing reduced density in oligotrophic bodies of water (Siver and Kling, 1997; Negro et al., 2000; Taylor et al., 2007). In the present study, the Aulacoseira species presented lower density in ultra-oligotrophic periods (May 2011).

The abundance of $A$. granulata var. granulata probably also indicates a phase of change associated with the increased turbidity and turbulence resulting from high rainfall, with the decrease in light availability optimizing their growth, and this explains their prominence in this period (Sommer and Stabel, 1983; Costa-Böddeker et al., 2012).

The highest values of TP and $\mathrm{pH}$ favored the development of Aulacoseira pusilla, a common species in lotic environments (Becker and Motta-Marques, 2004), preferring mesotrophic to eutrophic and reducing their densities in oligotrophic environments (Siver and Kling, 1997; Taylor et al., 2007). In the opposite situation, low $\mathrm{TP}$ and $\mathrm{pH}$, Pleurosira laevis species presented greater density, corroborating with studies by Branco et al. (2009) in rivers with $\mathrm{pH}$ 7.1-7.9 and Felisberto and Rodrigues (2010) with pH 6.0-7.0 and TP 5.7-26.3.

Although similar compositions were observed between the stations, the species exclusive to $\mathrm{S} 1$ were occasional and none were abundant. Most of these species (75\%) have been reported as abundant in nutrient-rich environments, and therefore, they are considered indicators of pollution in categories ranging from light to highly trophic conditions (Lowe, 1974; Moresco et al., 2011; Soares et al., 2011). The finding that diversity values were elevated may indicate that the stations, although they suffer the influence of human action, still maintain a diversity of algae species.
The species exclusive to S2 were also occasional, and none of these species were abundant in the samples. They have also been cited as highly tolerant to different environmental conditions, and some species (Discostella pseudostelligera, Stauroneis smithii, Sellaphora pupula and Surirella splendida) present preferences for oligotrophy (Jewson et al., 1993; Soares et al., 2011), corroborating with the trophic data of this station.

Many studies have considered the relationship of diatoms with pollution or perturbation processes, and many models of studies have demonstrated this (Kelly et al., 1998; Lobo et al., 2004; Chen et al., 2008, Mischke et al., 2011). However, the ecological information based on tolerance of some species of diatoms reflects seamlessly various environmental conditions, as is the case for rare species that may be indicative of oligotrophic conditions (Kociolek and Stoermer, 2009).

Regarding the assessment of biological indexes, higher values of diversity and evenness characterize a condition of high floristic diversity and relative uniformity of the population of planktonic diatoms, with peaks of fluctuation between stations. This fact may be related to more heterogeneous environmental conditions caused by environmental dynamics, a fact that was also observed in a study on total phytoplankton in the same locations by Menezes et al. (2013). Overall, this phytoplankton community showed a large number of species with low density values, which is a peculiarity of large rivers (Lamb and Lowe, 1987; Reynolds and Descy, 1996).

Although not frequent, many periphytic species were found, especially in the months of greater transparency and low levels of rainfall. This situation may occur due to the region surrounding the stations, due to the lowering of the river, presenting more substrate in the photic zone and thus a larger area for colonization (Lamb and Lowe, 1987). The influence of the current, even with less intensity, is still an important factor, which causes the removal of these algae from the substrate (Rimet and Bouchez, 2012; Lamb and Lowe, 1987). In rivers, the flow can improve the diffusion of nutrients supplying algae in layers of the matrix, which is an important factor in the case of waters with low nutrient levels (Balvay, 1981); in addition, a variation in water flow can change the composition and abundance of diatoms (Lamb and Lowe, 1987).

Variations in water flow were also found to cause significant changes in the diatom communities of the Cuarto River (Córdoba, Argentina). During periods of low flow with diatoms of large size, high flow led to diatoms of large size be replaced by smaller size diatoms (Martínez de Fabricius et al., 2003). The biological indexes, in turn, reinforced the characteristics of the sampled period and sites, indicating high evenness coming close to the theoretical maximum and showing high diversity.

The biodiversity of the planktonic diatom community was represented by a large number of taxa, with no dominant species but many rare species of periphytic origin (Lamb and Lowe, 1987; Reynolds and Descy, 1996; Baykal et al., 2011). Thus, the lack of dominance 
denotes the difficulty species have settling in a turbulent environment with scarce nutrients (Ward and Stanford, 1983; Lamb and Lowe, 1987).

Based on the hypothesis of this study, the factor that determined the community structure was the temporal variation (weather periods), presenting higher or lower densities in relation to processes resulting from rainfall: rain (turbidity, DO and BOD) and drought (transparency). Aulacoseira granulata var. granulata was the descriptor species for turbulence and turbidity, and Cocconeis placenta var. lineata was the descriptor species for transparency.

\section{Acknowledgements}

The authors would like to thank the Coordenação de Aperfeiçoamento de Pessoal de Nível Superior-CAPES, for the scholarship awarded to the first author; and the Gerpel/Unioeste (Grupo de Pesquisas em Recursos Pesqueiros e Limnologia) for providing us with the chemical analysis of samples. We thank Fernanda Ferrari, Vanessa Majewski Algarte and Susicley Jati, for their valuable comments and suggestions that greatly contributed to improving the final version.

\section{References}

AMERICAN PUBLIC ASSOCIATION - APHA, 2005. Standard Methods for the Examination of Water and Wastewater. 20th ed. Washington: APHA.

BALVAY, G., 1981. Evolution de l'oxygène dissous dans le lac d'Annecy. Thonon: INRA/SICRLA. 7 p.

BARTOZEK, E.C.R., BUENO, N.C., LUDWIG, T.A.V., TREMARIN, P.I., NARDELLI, M.S. and ROCHA, A.C.R., 2013. Diatomáceas (Bacillariophyceae) do Parque Nacional do Iguaçu, Foz do Iguaçu, Paraná. Acta Botanica Brasílica, vol. 27, no. 1, pp. 108-123. http://dx.doi.org/10.1590/S0102-33062013000100012.

BAYKAL, T., AÇIKGÖZ, I., UDOH, A.U. and YILDIZ, K., 2011. Seasonal variations in phytoplankton composition and biomass in a small lowland river-lake system (Melen River, Turkey). Journal of Biology, vol. 35, pp. 485-501.

BECKER, V. and MOTTA-MARQUES, D., 2004. Water dynamics, phytoplankton biomass and size structure of a shallow freshwater subtropical lake (Itapeva lake, south of Brazil). Acta Limnologica Brasiliensia, vol. 16, no. 2, pp. 163-174.

BICUDO, C.E.M. and MENEZES, M., 2006. Gêneros de água de águas continentais do Brazil: chave para identificação e descrições. São Carlos: Rima. 489 p.

BORGES, P.A.F., TRAIN, S. and RODRIGUES, L.C., 2008. Estrutura do fitoplâncton em curto período de tempo, em um braço do reservatório de Rosana (ribeirão do Corvo, Paraná, Brasil). Acta Scientiarum Biological Sciences, vol. 30, no. 1, pp. 57-65.

BRANCO, C.C.Z., PERES, C.K., KRUPEK, R.A. and BERTUSSO, F.R., 2009. Macroalgas de ambientes lóticos da região centro-oeste do Paraná, região sul do Brasil. Biota Neotropica, vol. 9, no. 2, pp. 227-235. http://dx.doi.org/10.1590/S1676-06032009000200022.

BRASSAC, N.M. and LUDWIG, T.A.V., 2003. Fragilariophyceae (Bacillariophyceae) de rios da bacia do Iguaçu. Paraná. Brasil. Revista Brasileira de Botanica. Brazilian Journal of Botany, vol. 26, no. 3, pp. 311-318. http://dx.doi.org/10.1590/S010084042003000300004 .

BRASSAC, N.M. and LUDWIG, T.A.V., 2005. Amphipleuraceae e Diploneidaceae (Bacilariophyceae) da bacia do rio Iguaçu. Paraná. Brasil. Acta Botanica Brasílica, vol. 19, no. 2, pp. 359-368. http:// dx.doi.org/10.1590/S0102-33062005000200019.

BRASSAC, N.M. and LUDWIG, T.A.V., 2006. Diatomáceas de rios da bacia do rio Iguaçu. Paraná. Brasil: Pinnularia e Caloneis. Hoehnea, vol. 33, no. 2, pp. 127-142.

CARLSON, R.E., 1977. A trophic state index for lakes. Limnology and Oceanography, vol. 22, no. 2, pp. 361-369. http://dx.doi. org/10.4319/lo.1977.22.2.0361

CENTIS, B., TOLOTTI, M. and SALMASO, N., 2010. Structure of the diatom community of the River Adige (North-Eastern Italy) along a hydrological gradient. Hydrobiologia, vol. 639, no. 1, pp. 37-42. http://dx.doi.org/10.1007/s10750-009-0019-z.

CHEN, G., DALTON, C., LEIRA, M. and TAYLOR, D., 2008. Diatom-based total phosphorus (TP) and $\mathrm{pH}$ transfer functions for the Irish Ecoregion. Journal of Paleolimnology, vol. 40, no. 1, pp. 143-163. http://dx.doi.org/10.1007/s10933-007-9148-4.

CONTIN, L.F., 1990. Contribuição ao estudo das diatomáceas (Chrysophyta. Bacillariophyceae) na região de captação d'água do rio Iguaçu (SANEPAR), em Curitiba. estado do Paraná, Brasil. Estudos de Biologia, vol. 24, pp. 5-95.

COSTA-BÖDDEKER, S., BENNION, H., JESUS, T.A., ALBUQUERQUE, A.L.S., FIGUEIRA, R.C.L. and BICUDO, D.C., 2012. Paleolimnologically inferred eutrophication of a shallow, tropical, urban reservoir in southeast Brazil. Journal of Paleolimnology, vol. 48, pp. 751-766. http://dx.doi.org/10.1007/ s10933-012-9642-1.

DAJOZ, R., 2005. Princípios de Ecologia. Porto Alegre: Artmed. $320 \mathrm{p}$.

DONG, X., BENNION, H., BATTARBEE, R.W., YANG, X., YANG, H. and LIU, E., 2008. Tracking eutrophication in Taihu Lake using diatom record: potential and problems. Journal of Paleolimnology, vol. 40, no. 1, pp. 413-429. http://dx.doi. org/10.1007/s10933-007-9170-6.

ESTEVES, F.A. and SUZUKI, M.S., 2011. Comunidade fitoplânctonica. In: F.A. ESTEVES. Fundamentos de Limnologia. Rio de Janeiro: Interciência, pp. 375-445.

FELISBERTO, A.S. and RODRIGUES, L., 2010. Periphytic algal community in artificial and natural substratum in a tributary of the Rosana reservoir (Corvo Stream, Paraná State, Brazil). Acta Scientiarum Biological Sciences, vol. 32, no. 4, pp. 373-385. http://dx.doi.org/10.4025/actascibiolsci.v32i4.4627.

FERRARI, F. and LUDWIG, T.A.V., 2007. Coscinodiscophyceae, Fragilariophyceae e Bacillariophyceae (Achnanthales) dos rios Ivaí, São João e dos Patos, bacia hidrográfica do rio Ivaí, município de Prudentópolis, PR. Brasil. Acta Botanica Brasílica, vol. 21, no. 2, pp. 421-441. http://dx.doi.org/10.1590/S0102-33062007000200016.

HAMMER, Ø., HARPER, D.A.T. and RYAN, P.D., 2011. Paleontological Statistics Software Package for Education and Data Analysis. Palaeontologia Electronica, vol. 4, no. 1, pp. 1-9.

HILL, W., 1996. Effects of light. In: J. STEVENSON, M.L. BOTHWELL and R.L. LOWE eds. Algal ecology: freshwater benthic ecosystems. San Diego: Academic Press, pp. 121-148.

JADHAV, S., BORDE, S. and JADHAV, D., 2011. Study of seasonal variations of some physico-chemical characteristics of 
Sina Kolegoan dam at Osmanabad district (M.S.). International Multidisciplinary Research Journal, vol. 1, no. 12, pp. 19-20.

JEWSON, D.H., KHONDKER, M., RAHMAN, M.H. and LOWRY, S., 1993. Auxosporulation of the freshwater diatom Aulacoseira herzogii in lake Banani. Bangladesh. Diatom Research, vol. 8, no. 2, pp. 403-418. http://dx.doi.org/10.1080/0269249X.1993.9705270.

KELLY, M.G., CAZAUBON, A., CORING, E., DELL'UOMO, A., ECTOR, L., GOLDSMITH, B., GUASCH, H., HÜRLIMANN, J., JARLMAN, A., KAWECKA, B., KWANDRANS, J., LAUGASTE, R., LINDSTRØM, E.-A., LEITAO, M., MARVAN, P., PADISÁK, J., PIPP, E., PRY GIEL, J., ROTT, E., SABATER, S., VAN DAM, H. and VIZINET, J., 1998. Recommendations for the routine sampling of diatoms for water quality assessments in Europe. Journal of Applied Phycology, vol. 10, no. 2, pp. 215-224. http:// dx.doi.org/10.1023/A:1008033201227.

KOCIOLEK, J.P. and STOERMER, E.F., 2009. Oligotrophy: the forgotten end of an ecological spectrum. Acta Botany Croatica, vol. 68 , no. 2 , pp. $465-472$.

LACTEC, 2005. Previsão de Vazões na Bacia do Rio Iguaçu com Incorporação de Informações de Precipitação - Metodologia a ser empregada no processo de previsão pelo modelo SMAP: Projeto Hg-210. Curitiba: LACTEC. Relatório Técnico, no. 3.

LAMB, M.A. and LOWE, R., 1987. Effects of current velocity on the physical structuring of diatom (Bacillariophyceae) communities. The Ohio Journal of Science, vol. 87, no. 3, pp. 72-78.

LAMPARELLI, M.C., 2004. Grau de trofia em corpos d'água do estado de São Paulo: avaliação dos métodos de monitoramento. São Paulo: Universidade de São Paulo, Departamento de Ecologia, 235 p. Tese de doutorado em Ciências na Área de Ecossistemas Terrestres e Aquáticos.

LOBO, E. and LEIGHTON, G., 1986. Estruturas comunitárias de las fitocenosis planctónicas de los sistemas de desembocaduras de rios y esteros de La zona Central de Chile. Revista de Biologia Marina, vol. 22, no. 1, pp. 1-29.

LOBO, E.A., CALLEGARO, V.L., HERMANY, G., BES, D., WETZEL, C.E. and OLIVEIRA, M.A., 2004. Use of epilithic diatoms as bioindicator from lotic systems in southern Brazil, with special emphasis on eutrophication. Acta Limnologica Brasiliensia, vol. 16, no. 1, pp. 25-40.

LOWE, R.L., 1974. Environmental requirements and pollution tolerance of freshwater diatoms. Washington: Office of Research and Development. U.S. Environmental Protection Agency. 334 p.

MACKERETH, F.J.H., HERON, J. and TALLING, J.F., 1978. Water analysis: some revised methods for limnologists. Cumbria. Scientific Publication - Freshwater Biological Association, no. 36, pp. 120p.

MARKER, A.F.H., NUSH, E.A., RAI, H. and RIEMAN, B., 1980. The measurements of photosynthetic pigments in freshwaters and standardization of methods: conclusions and recommendations. Archives Hydrobiology Beith. Ergbn Limnology, vol. 14, pp. 91-106.

MARQUARDT, G.C., FURSTENBERGER, C.B., CHAOUICHE, T.E., CAPARICA, R. and CARAPUNARLA, L., 2010. Diatomáceas (Bacillariophyceae) perifíticas em substratos naturais do rio das Pedras, município de Guarapuava, Paraná, Brasil. Terra Plural, vol. 4, no. 2, pp. 217-240. http://dx.doi.org/10.5212/ TerraPlural.v.4i2.0005.

MARTÍNEZ DE FABRICIUS, A.L., MAIDANA, N., GÓMEZ, N. and SABATER, S., 2003. Distribution patterns of benthic diatoms in a Pampean river exposed to seasonal floods: the Cuarto River
(Argentina). Journal Biodiversity \& Conservation, vol. 12, no. 12, pp. 2443-2454. http://dx.doi.org/10.1023/A:1025857715437.

MENEZES, V.C., BUENO, N.C. and RODRIGUES, L.C., 2013. Spatial and temporal variation of the phytoplankton community in a section of the Iguaçu River, Paraná, Brazil. Brazilian Journal of Biology $=$ Revista Brasileira de Biologia, vol. 73, no. 2, pp. 279-290. http://dx.doi.org/10.1590/S1519-69842013000200008. PMid:23917555.

MISCHKE, U., VENOHR, M. and BEHRENDT, H., 2011. Using phytoplankton to assess the trophic status of German Rivers. International Review of Hydrobiology, vol. 96, no. 5, pp. 578598. http://dx.doi.org/10.1002/iroh.201111304.

MONNIER, O., RIMET, F., BEY, M., CHAVAUX, R. and ECTOR, L., 2007. Sur l'identité de Cocconeis euglypta Ehrenberg 1854 et $C$. lineata Ehrenberg 1843- Une approche par les sources historiques. Diatomania, vol. 11, pp. 30-45.

MOREIRA-FILHO, H. and VALENTE-MOREIRA, I.M., 1981. Avaliação taxonômica e ecológica das diatomáceas (Bacillariophyceae) epífitas em algas pluricelulares obtidas nos litorais dos Estados do Paraná, Santa Catarina e São Paulo. Boletim do Museu Botânico Municipal, vol. 47, pp. 1-17.

MORESCO, C., TREMARIN, P.I., LUDWIG, T.A.V. and RODRIGUES, L., 2011. Diatomáceas perifíticas abundantes em três córregos com diferentes ações antrópicas em Maringá, PR, Brasil. Revista Brasileira de Botanica. Brazilian Journal of Botany, vol. 34, no. 3, pp. 359-373. http://dx.doi.org/10.1590/ S0100-84042011000300010.

MOURA, A.N., SEVERIANO, J.S., TAVARES, N.K.A. and DANTAS, E.W., 2013. The role of a cascade of reservoirs and seasonal variation in the phytoplankton structure in a tropical river. Brazilian Journal of Biology $=$ Revista Brasileira de Biologia, vol. 73, no. 2, pp. 291-298. http://dx.doi.org/10.1590/ S1519-69842013000200009. PMid:23917556.

NABOUT, J.C., NOGUEIRA, I.S., OLIVEIRA, L.G. and MORAIS, R.R., 2007. Phytoplankton diversity (alpha, beta, and gamma) from the Araguaia River tropical floodplain lakes (central Brazil). Hydrobiologia, vol. 557, no. 1, pp. 455-461. http://dx.doi. org/10.1007/s10750-006-0393-8.

NEGRO, A.I., HOYOS, C. and VEGA, J.C., 2000. Phytoplankton structure and dynamics in lake Sanabria and Valparaiso reservoir (NWSpain). Hydrobiologia, vol. 424, no. 1, pp. 25-37. http:// dx.doi.org/10.1023/A:1003940625437.

PARANÁ. Instituto das Águas do Paraná, 2010 [viewed 9 Abril 2011]. Folders de Bacias Hidrográficas [online]. Available from: http://www.aguasparana.pr.gov.br/modules/conteudo/conteudo. php? conteudo $=38$.

PASSY, S.I., 2007. Differential cell size optimization strategies produce distinct diatom richness-body size relationships in stream benthos and plankton. Journal of Ecology, vol. 95, no. 4, pp. 745-754. http://dx.doi.org/10.1111/j.1365-2745.2007.01248.x.

PEEL, M.C., FINLAYSON, B.L. and MCMAHON, T.A., 2007. Updated world map of the Köppen-Geiger climate classification. Hydrology and Earth System Sciences, vol. 11, no. 5, pp. 16331644. http://dx.doi.org/10.5194/hess-11-1633-2007.

REYNOLDS, C.S. and DESCY, J.P., 1996. The production, biomass and structure of phytoplankton in large rivers. Archiv für Hydrobiologie, vol. 113, no. 4, pp. 161-187.

RIMET, F. and BOUCHEZ, A., 2012. Life-forms, cell-sizes and ecological guilds of diatoms in European rivers. Formes de vie, 
tailles de cellule et guildes écologiques des diatomées des rivières européennes. Knowl. Managt. Aquatic Ecosystems, vol. 406, no. 01, pp. 1-12. http://dx.doi.org/10.1051/kmae/2012018.

ROUND, F.E., CRAWFORD, R.M. and MANN, D.G., 1990. The diatoms. Biology e morphology of the genera. New York: Cambridge University Press. 747 p.

SALAMUNI, R., SALAMUNI, E., ROCHA, L.A. and ROCHA, A.L., 2002. Parque Nacional do Iguaçu, PR: Cataratas de fama mundial. In: C. SCHOBBENHAUS, D.A. CAMPOS, E.T. QUEIROZ, M. WINGE and M.L.C. BERBERT-BORN, eds. Sítios geológicos e paleontológicos do Brasil. Brasília: DNPM/ CPRM (SIGEP), pp. 313-321.

SANTOS, E.M., TREMARIN, P.I. and LUDWIG, T.A.V., 2011. Diatomáceas perifíticas em Potamogeton polygonus Cham. and Schltdl: citações pioneiras para o estado do Paraná. Biota Neotropica, vol. 11, no. 3, pp. 303-315. http://dx.doi.org/10.1590/ S1676-06032011000300025.

SIVER, P.A. and KLING, H., 1997. Morphological observations of Aulacoseira using scanning electron microscopy. Canadian Journal of Botany, vol. 75, no. 11, pp. 1807-1835. http://dx.doi. org/10.1139/b97-894.

SMOL, J.P. and STOERMER, E.F., 2010. The diatoms: applications for the environmental and earth sciences. Cambridge: Cambridge University Press. 667 p.

SOARES, F.S., KONOPLYA, B.I.B., SILVA, J.F.M. and ANDRADE, C.G.T.J., 2011. Amphipleuraceae (Bacillariophyceae) do alto da bacia do Ribeirão Cambé. Londrina. Brasil. Revista Brasileira de Botanica. Brazilian Journal of Botany, vol. 34, no. 1, pp. 39-49. http://dx.doi.org/10.1590/S0100-84042011000100005.

SOLORZANO, L., 1969. Determination of ammonia in natural waters by the phenolhypochlorite method. Limnology and Oceanography, vol. 14, no. 5, pp. 799-801. http://dx.doi. org/10.4319/1o.1969.14.5.0799.

SOMMER, U. and STABEL, H., 1983. Silicon Consumption and Population Density Changes of Dominant Planktonic Diatoms in Lake Constance. Journal of Ecology, vol. 71, no. 1, pp. 119-130. http://dx.doi.org/10.2307/2259966.

STEVENSON, R.J. and PAN, Y., 1999. Assessing environmental conditions in rivers and streams with diatoms. In: E.F. STOERMER and J.P. SMOL, eds. The diatoms: applications for the environmental and earth sciences. Cambridge: Cambridge University Press, pp. 11-40.

TAYLOR, J.C., HARDING, W.R. and ARCHIBALD, G.M., 2007. An Illustrated Guide to Some Common Diatom Species from South Africa. WRC Report TT.
TER-BRAAK, C.J.F., 1986. Canonical Correspondence Analysis: A New Eigenvector Technique for Multivariate Direct Gradient Analysis. Ecological Society of America, vol. 67, no. 5, pp. 1167-1179.

TRAIN, S., 1991. Diatomáceas (Bacillariophyceae) do córrego Moscados, Maringá, Paraná: Bacillariaceae. Revista Unimar, vol. 13 , no. 2 , pp. 313-326.

TREMARIN, P.I., BERTOLLI, L.M., FARIA, D.M., COSTIN, J.C. and LUDWIG, T.A.V., 2009. Gomphonema Ehrenberg e Gomphosphenia Lange-Bertalot (Bacillariophyceae) do Rio Maurício, Paraná, Brasil. Biota Neotropica, vol. 9, no. 4, pp. 111-130. http://dx.doi.org/10.1590/S1676-06032009000400013.

TREMARIN, P.I., LUDWIG, T.A.V. and MOREIRA-FILHO, H., 2008. Thalassiosirales (Diatomeae) do rio Guaraguaçu. Bacia Litorânea. PR. Brasil. Acta Botanica Brasílica, vol. 22, no. 4, pp. 1101-1113. http://dx.doi.org/10.1590/S0102-33062008000400021.

TUNDISI, J.G. and MATSUMURA-TUNDISI, T.M., 2008. Limnologia. São Paulo: Oficina de textos. 632 p.

TUNDISI, J.G., 2003. Água no século XXI: enfrentando a escassez. São Carlos: RIMA. 248 p.

UNESCO, 2002. Patrimônio mundial no Brasil. 2nd ed. Brasília: Caixa Econômica Federal. 291 p.

UTERMÖHL, H., 1958. Zur Vervollkommung der quantitativen Phytoplankton-Methodic. Mitteilungen Internatinale Vereinigung für Theoretische und Angewandte Limnologie, vol. 9, pp. 1-38.

VAN DAM, H., MERTENS, A. and SINKELDAM, J., 1994. A coded checklist and ecological indicator values of freshwater diatoms from the Netherlands. Netherlands Journal of Aquatic Ecology, vol. 28, no. 1, pp. 117-133. http://dx.doi.org/10.1007/ BF02334251.

VELOSO, H.P., RANGEL-FILHO, A.L.R. and LIMA, J.C.A., 1991. Classificação da vegetação brasileira, adaptada a um sistema universal. Rio de Janeiro: IBGE. 124 p.

WARD, J.V. and STANFORD, J.A., 1983. The serial discontinuity concept in lotic ecosystems. In: T.D. FONTAINE and S.M. BARTHELL, eds. Dynamics of lotic ecosystems. Michigan: Ann Arbor Science, pp. 29-42.

WEHR, J.D. and DESCY, J.P., 1998. Use of phytoplankton in large river management. Journal of Phycology, vol. 34, no. 5, pp. 741-749. http://dx.doi.org/10.1046/j.1529-8817.1998.340741.x.

ZAR, J.H., 1998. Biostatistical analysis. 4th ed. Upper Saddle River: Prentice Hall. 929 p. 